\title{
MODIFICATION OF THE CATALYTIC SYSTEM OR THE INDUSTRIAL CHLORINE PROCESSING OF ETHYLENE IN 1,2-DICHLOROETHANE
}

\author{
Volodymyr Starchevskyy ${ }^{1}$, Mykola Shparij ${ }^{1}$, Yurii Hrynchuk $^{1}$, \\ Volodymyr Reutskyy ${ }^{1}$, Sergiy Kurta ${ }^{2}$, Olga Hatsevych ${ }^{2}$
}

https://doi.org/10.23939/chcht14.03.394

\begin{abstract}
A new mechanism for the reaction of direct (additive) chlorination of ethylene with chlorine from the formation of 1,2-dichloroethane in the presence of $\mathrm{FeCl}_{3}$ catalyst promoted by $\mathrm{NaCl}$ has been proposed. It was found that the rate depends on the active phase concentration of the catalyst and the promoter, as well as the formation of the $\mathrm{Na}\left[\mathrm{Fe}\left(\mathrm{C}_{2} \mathrm{H}_{4} \mathrm{Cl}\right)_{4}\right]$ complex, which is a surface intermediate of the reaction. The heterogeneous-homogeneous mechanism of the process, according to which the reaction begins on the surface of the catalytic complex and lasts in a solution of dichloroethane, has been substantiated. A stabilizer of the catalyst complex - the sodium salt of perforated sulfonic acid, which accelerates the process of dissolution of sodium chloride, - increases the selectivity of 1,2-dichloroethane formation and reduces the number of by-products of trichloroethane and other chlorine derivatives.
\end{abstract}

Keywords: ethylene, chlorine, dichloroethane, additive chlorination, catalyst, promoter, mechanism, stabilizer, ammonium chloride, sodium salt of perforated sulfonic acid.

\section{Introduction}

At the production of 1,2-dichloroethane at "Karpatnaftokhim" LLC in Kalush, Ukraine, the balanced scheme of 1,2-dichloroethane (DCE) is obtained by the oxidation and direct chlorination of ethylene by the addition of chlorine relative to the double bonding of ethylene. In the process of ethylene direct chlorination with chlorine gas in a medium of liquid DCE under pressure of $(3-4) \cdot 10^{6} \mathrm{~Pa}$ and the temperature of $353-$ $389 \mathrm{~K}$, the accession reaction proceeds in the presence of

\footnotetext{
${ }^{1}$ Lviv Polytechnic National University,

12, Bandery St., 79013 Lviv, Ukraine

${ }^{2}$ Vasyl Stefanyk Pricarpatian National University,

57, Shevchenka St., 76000 Ivano-Frankivsk, Ukraine

vstarchevskyy@gmail.com

(C) Starchevskyy V., Shparij M., Hrynchuk Yu., Reutskyy V., Kurta S., Hatsevych O., 2020
}

a catalyst - iron(III) chloride $\left(\mathrm{FeCl}_{3}\right)$ and a reaction promoter - sodium chloride $(\mathrm{NaCl})$. According to the literature, it is believed that the following reactions occur, where the catalyst is a carrier of chlorine [1]:

$$
\begin{gathered}
\mathrm{CH}_{2}=\mathrm{CH}_{2}+\mathrm{Cl}_{2} \rightarrow \mathrm{CH}_{2} \mathrm{Cl}-\mathrm{CH}_{2} \mathrm{Cl} \\
\mathrm{FeCl}_{3}+\mathrm{Cl}_{2} \rightarrow \mathrm{FeCl}_{4}^{+}+\mathrm{Cl}^{-} \\
\mathrm{FeCl}_{4}^{+}+\mathrm{Cl}^{-}+\mathrm{CH}_{2}=\mathrm{CH}_{2} \rightarrow \mathrm{ClCH}_{2}- \\
\mathrm{CH}_{2} \mathrm{Cl}+\mathrm{FeCl}_{3}
\end{gathered}
$$

The mechanism of $\mathrm{FeCl}_{3}$ catalytic action described in the literature [2] consists in the electrophilic attachment of chlorine to ethylene with the formation of $\pi$ and $\delta$ complexes between catalyst, promoter, and ethylene. Thus, $\mathrm{FeCl}_{3}$ together with $\mathrm{NaCl}$ is a carrier of chlorine ions in the addition reaction to ethylene [3]. The structure of these compounds separately from each other is well described by Furman [4], but the compounds formed by their interaction in the DCE medium have not been studied yet, and needed the attention [5] to elucidate the mechanism of ethylene direct chlorination and to select the new, more efficient catalyst complex promoters and stabilizers in the industrial process.

\section{Experimental}

To study the mechanism of ethylene direct chlorination, it was necessary to study the structure of the catalyst and promoter in the catalytic complex [6]. For the analysis of the industrial sample of catalyst and promoter $\left(\mathrm{FeCl}_{3} / \mathrm{NaCl}\right)$ of direct chlorination of ethylene, we used a chromatographic method to determine the content of micro-impurities in DCE using a Carlo Erba GC 8000 series chromatograph with a flame ionization detector, as well as DTA methods, phase X-ray structure on DRON$\mathrm{UM} 1$ in Co-K radiation with Fe filter in reflected rays and mass spectrometric analysis of MALDI-ToF and LDI-ToF matrix-activated laser desorption/ionization and laser desorption/ionization. Both methods were equipped with a time analyzer and implemented on an Autoflex II LRF 20 Bruker Daltonics device equipped with a pulsed nitrogen laser ( $\lambda=337 \mathrm{~nm}, 3 \mathrm{~ns}$ pulse time). Samples in solution or 
specimens in the matrix were applied on a standard steel target and dried under standard conditions. Each mass spectrum obtained during the study is the sum of 200 individual mass spectra. The analyzer was used under a linear mode. The studies were performed in the range of 100-6000 Da. Matrices for MALDI-ToF mass spectrometric studies were prepared according to the standard procedures: $12 \mathrm{mg} \mathrm{SA}$ (Fluka sinapinic acid) was dissolved in $1 \mathrm{ml}$ of a 1:1 water-isopropanol mixture. Trifluoroacetic acid in $1 \mu \mathrm{l}$ aliquot was added to the solution. Three catalyst samples prepared under different conditions were investigated:

Sample 1: $\mathrm{FeCl}_{3}+\mathrm{NaCl}$ - solid mechanical mixture of crystalline components, jointly grounded in a ball mill;

Sample 2: $\mathrm{FeCl}_{3}+\mathrm{NaCl}+\mathrm{H}_{2} \mathrm{O}$ - solid, dried precipitate from aqueous solution;

Sample 3: $\mathrm{FeCI}_{3}+\mathrm{NaCl}+\mathrm{DCE}$ - solid, dried precipitate from DCE solution (industrial catalyst) of the corresponding concentrations and ratios of $\mathrm{FeCl}_{3}: \mathrm{NaCl}$ as $(100-1000):(10-100) \mathrm{ppm}$, the preparation of which is described in [6].

According to the literature data, there are various technological schemes and reactors for direct chlorination of ethylene in the liquid phase [7], but they do not have much difference in structure [8], so the use of other types of catalysts $\mathrm{FeCl}_{2}, \mathrm{FeCl}_{3}, \mathrm{SnCl}_{4}$, and $\mathrm{SbCl}_{5}$ with nitrogencontaining donors, such as hexamethylphosphoritriamide or pyridine, and radical-inhibitors such as 2,6-di-tert-butyl-4methyl-phenol, $p$-nitrophenol, 2,2-di( $p$-oxyphenyl) propane are of top priority $[9,10]$.

\section{Results and Discussion}

\subsection{Investigation of the Catalytic Complex of Iron and Sodium Chlorides}

To determine the optimum temperatures for catalyst and promoter dechlorination $\left(\mathrm{FeCl}_{3} / \mathrm{NaCl}\right)$, we performed a DTA analysis of the samples (Fig. 1). The studied three samples quite differ from each other. Thus, one can see in TG diagrams that in the range of operating temperatures of ethylene direct chlorination (reaction 1) from 353 to $473 \mathrm{~K}$ the mechanical mixture of catalyst and promoter 1 - only $10 \%$, and the mixture 2 , obtained by evaporation from their aqueous solution have the smallest weight loss $(10 \%$ and $16 \%$, respectively) during the catalyst $\left(\mathrm{FeCl}_{3} / \mathrm{NaCl}\right)$ dechlorination at $393 \mathrm{~K}$. It means that under normal conditions, they do not form any intermediate compounds, since these chlorides of iron and sodium are thermally stable [10].

At the same time, for the sample 3 (Fig. 1a), which is a solid, dried precipitate from DCE solution (working catalyst), these losses during heating are the greatest and reach $30 \%$, which indicates the decomposition of the newly formed catalyst complex and the promoter at dechlorination. A more detailed analysis of DTG curves shows that only sample 1 (Fig. 1b) has two maximum decomposition rates of two intermediate compounds at 398 and $453 \mathrm{~K}$, while mechanical mixture (sample 3) and mixture of aqueous solution (sample 2) have only one maximum decomposition of one compound around $453 \mathrm{~K}$. Obviously, there are two intermediate compounds in the working catalyst $\left(\mathrm{FeCl}_{3}+\mathrm{NaCl}+\mathrm{DCE}\right)$, the summary losses of which at $473 \mathrm{~K}$ increase up to $24 \%$, and the total losses are the largest and reach $42 \%$, in contrast to the sample 1 and sample 2 (33\% and $24 \%$, respectively).

Fig. 2 shows diffraction patterns for all three samples. A new weakly crystalline $\mathrm{FeCl}_{\mathrm{n}}$ phase is observed for $\mathrm{FeCl}_{3}+\mathrm{NaCl}+\mathrm{DCE}$ at $2 \theta=12.5^{\circ}$, which indicates the possibility of compounds formation between the catalyst and the promoter, as shown by authors for anhydrous tetrachloroferrates [11].

The $\mathrm{NaCl}$ and $\mathrm{FeCl}_{n}$ ratio in the samples 2 and 3 is different. $\mathrm{NaCl}$ prevails in sample 2, and $\mathrm{FeCl}_{\mathrm{n}}$ in sample 3 . Thus, we can talk about the formation of two intermediate compounds between $\mathrm{NaCl}$ and $\mathrm{FeCl}_{\mathrm{n}}$ for sample 3; the same we observed using DTA analysis. Moreover, we assume the polyvalence of ferric chlorides $\mathrm{Fe}^{+1,2,3, \mathrm{n}}$ in its $\mathrm{FeCl}_{\mathrm{n}}$ compounds together with $\mathrm{NaCl}$, which implies the formation of complex compounds of $\mathrm{Na}\left(\mathrm{FeCl}_{\mathrm{n}}\right)$ type, where $\mathrm{n}=1,2,3,4$.

To determine the structure of the catalyst intermediate and the $\mathrm{Na}\left(\mathrm{FeCl}_{\mathrm{n}}\right)$ promoter in the catalytic complex obtained in different media, mass spectroscopy of all above mentioned samples was performed (Fig. 3). There was a large difference between the dependence of vapor pressure on the temperature under thermal desorption mass spectroscopy for the ethylene direct chlorination catalyst $\left(\mathrm{NaCl} / \mathrm{FeCl}_{3}\right)$ prepared in different media. The graphs show that, unlike the mechanical mixture (Fig. 3c) and the mixture obtained from an aqueous solution of catalyst and promoter (Fig. 2a), there are two desorption peaks at $353 \mathrm{~K}$ for $\mathrm{FeCl}_{3}$ and at $393 \mathrm{~K}$ for the sample prepared from DCE solution, which confirms the two-component nature of $\mathrm{Na}\left(\mathrm{FeCl}_{4}\right)$ complex.

The residues of $\mathrm{NaCl} / \mathrm{FeCl}_{3}$ crystals decomposition are clearly observed in Fig. 4a for the sample 1 $\left(\mathrm{NaCl}+\mathrm{FeCl}_{3}\right)$. The residues may be atomic chlorine (atomic mass 35-36) or molecular hydrogen chloride (molecular mass 36-38). At the same time, after drying the sample 2 (Fig. 4b), new residues of water decomposition (molecular mass 16-18) and salt crystalline hydrates appear; after drying sample $3\left(\mathrm{NaCl}+\mathrm{FeCl}_{3}+\mathrm{DCE}\right.$, Fig. $\left.4 \mathrm{c}\right)$ we observe the adsorbed residues of destructed ethylene and DCE (molecular mass of $\mathrm{C}_{\mathrm{x}} \mathrm{H}_{\mathrm{y}} \mathrm{Cl}_{\mathrm{z}}=24-28$ ). Obviously, when preparing $\mathrm{FeCl}_{3}$ catalyst and $\mathrm{NaCl}$ promoter in the DCE medium, the intermediate complexes 
can be formed between them, which serve as a catalyst for the direct chlorination process of ethylene, which is a part of the intermediate catalytic complex $\mathrm{Na}\left[\mathrm{Fe}\left(\mathrm{C}_{2} \mathrm{H}_{4} \mathrm{Cl}\right)_{4}\right]$

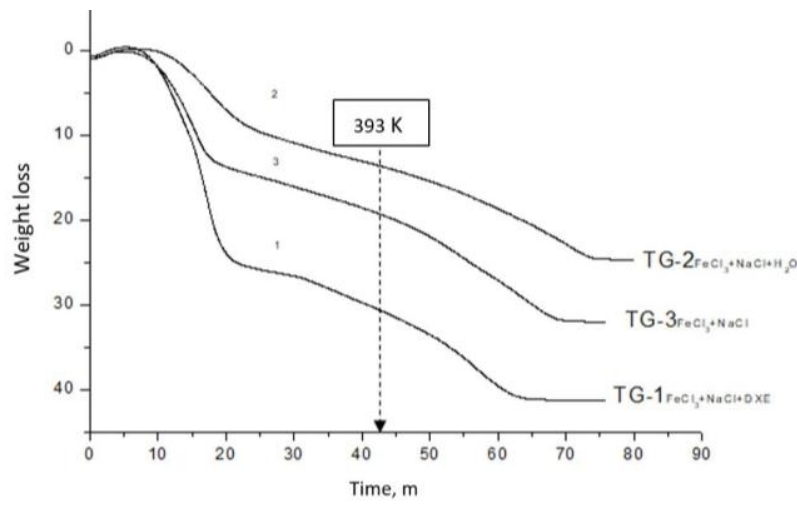

a) (reaction 4). So, we have proposed a new catalyst structure and mechanism for this reaction, which is described below.

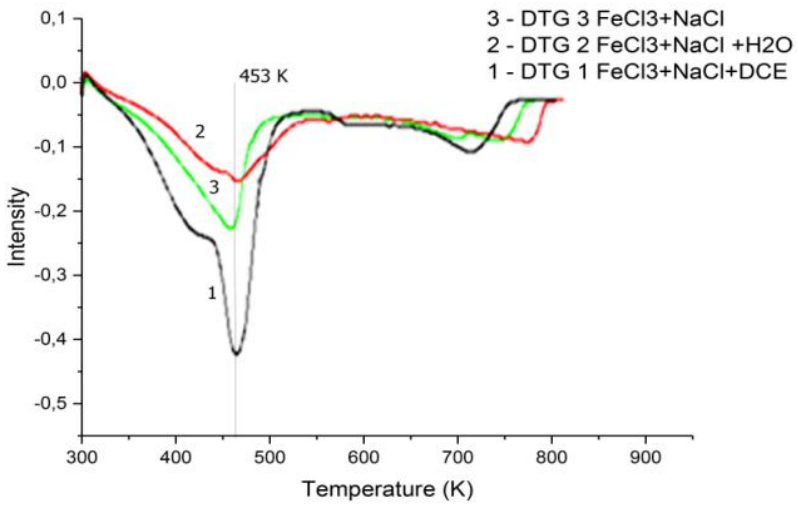

b)

Fig. 1. TG (a) and DTG (b) curves of the catalyst and promoter of the ethylene direct chlorination obtained in different media: $\mathrm{FeCl}_{3}+\mathrm{NaCl}+\mathrm{DCE}(1) ; \mathrm{FeCl}_{3}+\mathrm{NaCl}+\mathrm{H}_{2} \mathrm{O}$ (2) and $\mathrm{FeCl}_{3}+\mathrm{NaCl}(3)$. For (3) $\mathrm{FeCl}_{3}: \mathrm{NaCl}=10: 1$

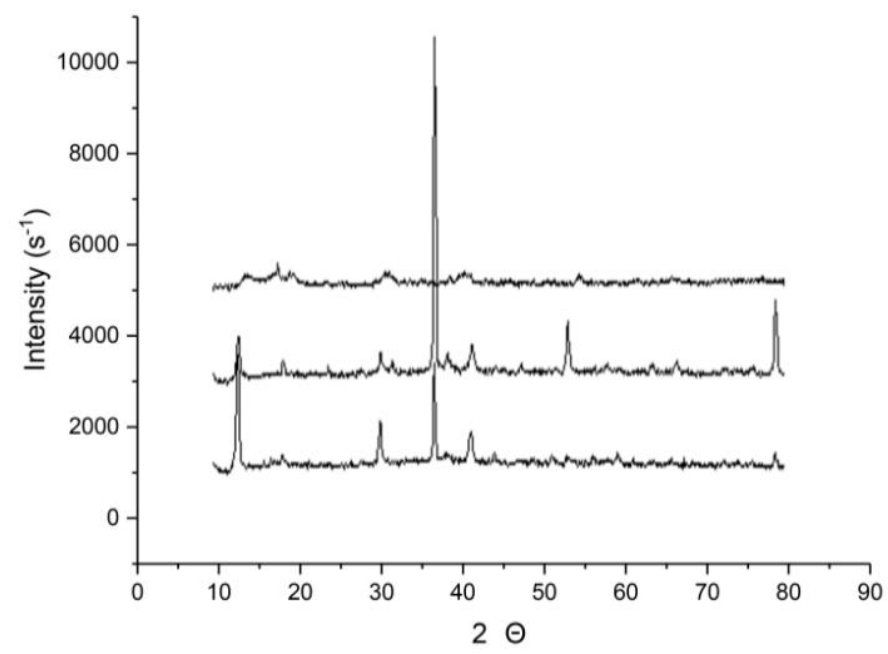

Fig. 2. Diffraction patterns of three samples of the direct chlorination catalyst prepared under different conditions: $\mathrm{FeCl}_{3}+\mathrm{NaCl}$ cryst. (1); $\mathrm{FeCl}_{3}+\mathrm{NaCl}+\mathrm{H}_{2} \mathrm{O}$ (2) and $\mathrm{FeCl}_{3}+\mathrm{NaCl}+\mathrm{DCE}$ (3). For (1) $\mathrm{FeCl}_{3}: \mathrm{NaCl}=10: 1$

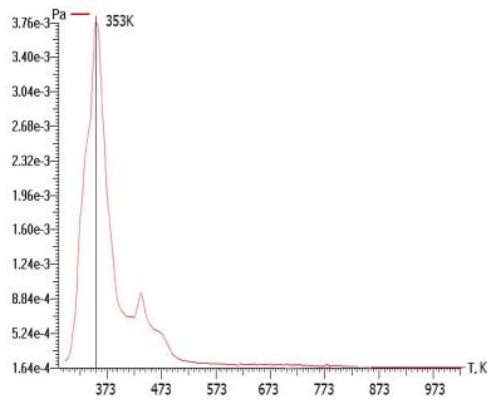

a)

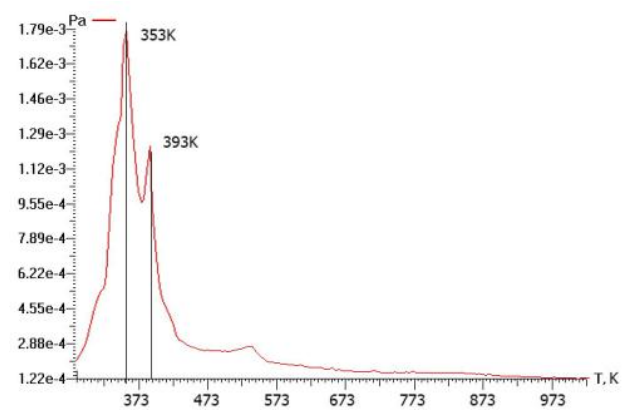

b)

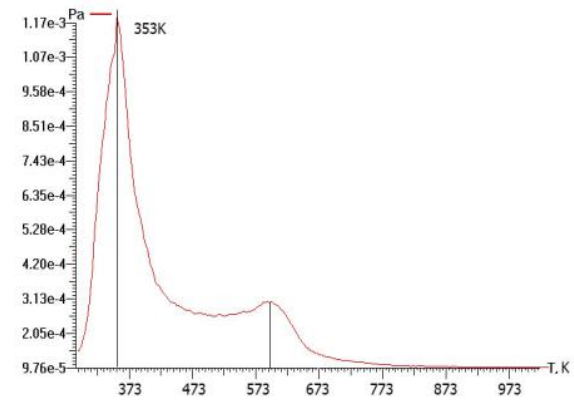

c)

Fig. 3. Vapor pressure $v s$. temperature at mass spectroscopy for ethylene direct chlorination catalyst $\left(\mathrm{NaCl} / \mathrm{FeCl}_{3}\right)$ in different media: $\mathrm{FeCl}_{3}+\mathrm{NaCl}+\mathrm{H}_{2} \mathrm{O}(\mathrm{a}) ; \mathrm{FeCl}_{3}+\mathrm{NaCl}+\mathrm{DCE}$ (b) and $\mathrm{FeCl}_{3}+\mathrm{NaCl}$ (c) 

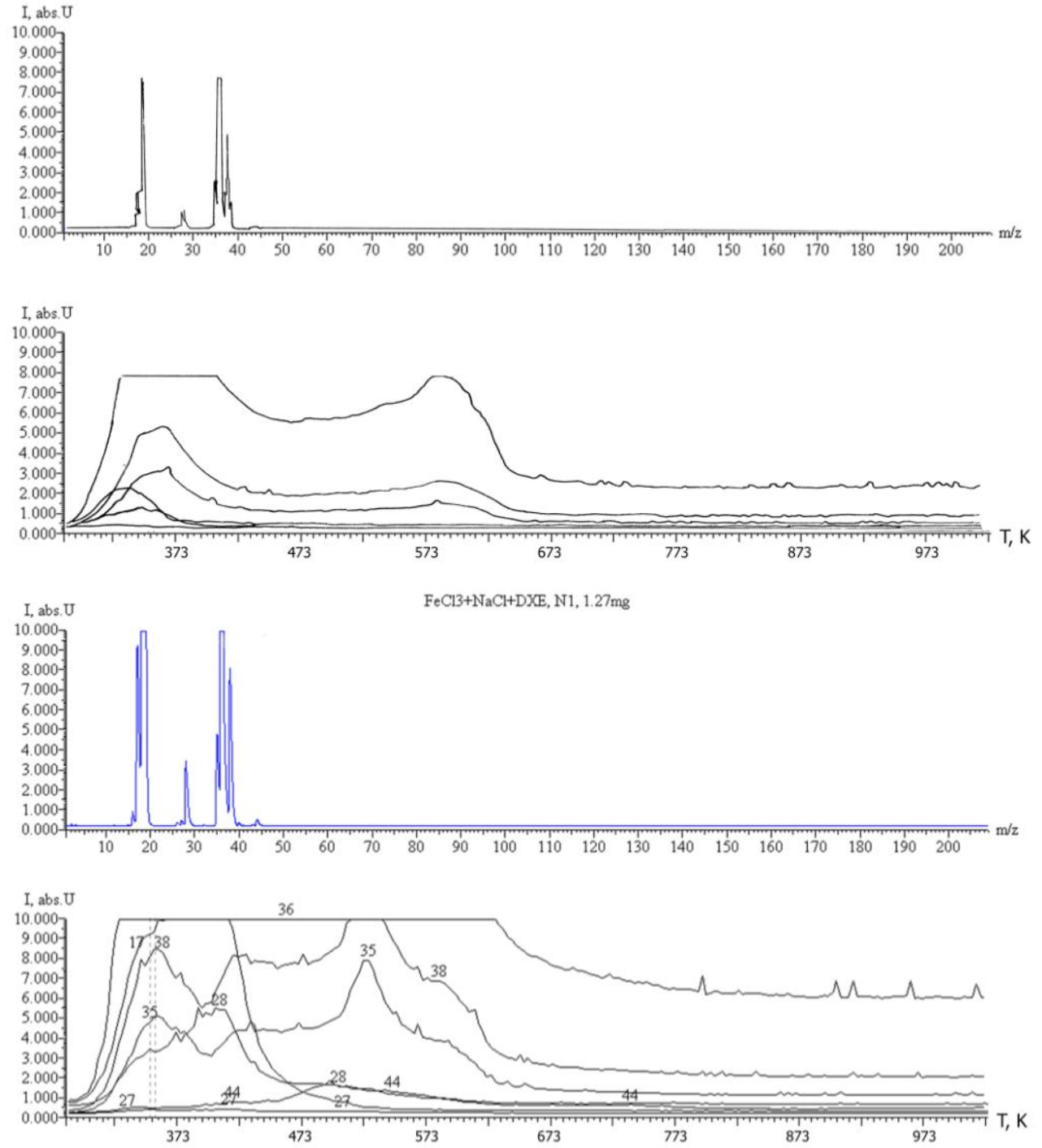

b)
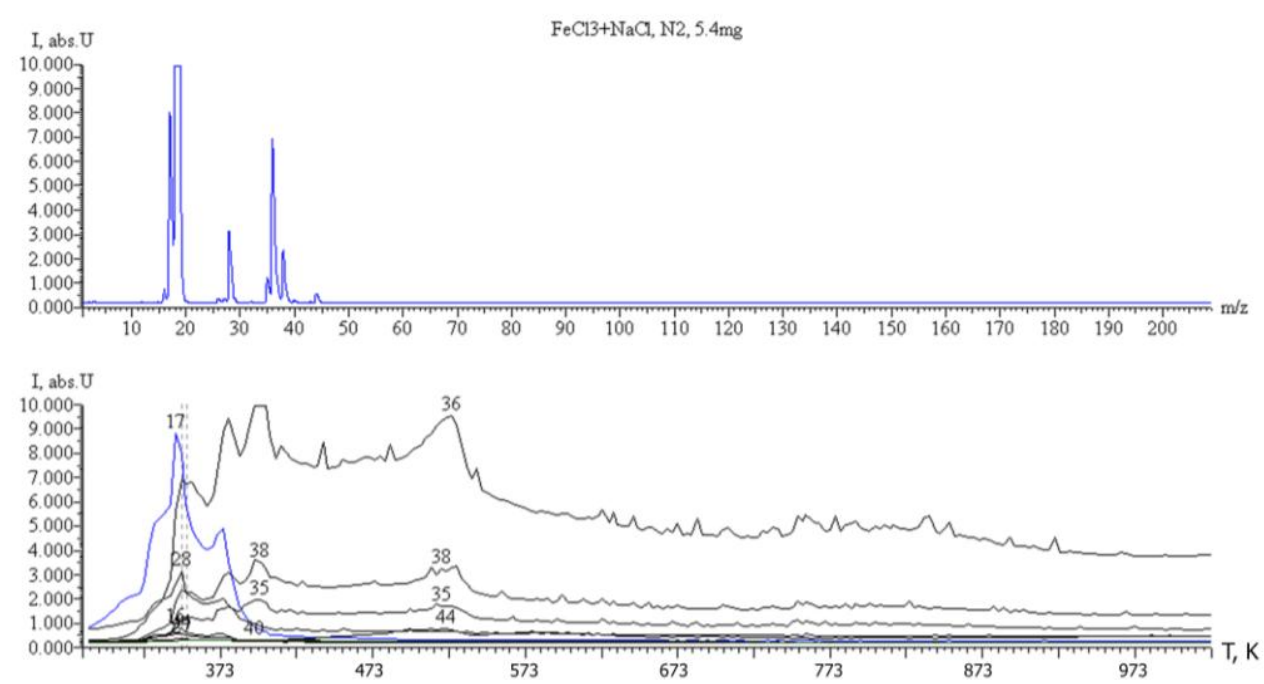

c)

Fig. 4. Thermodesorption mass spectroscopic curves of the catalyst active phase decomposition for $\mathrm{NaCl}+\mathrm{FeCl}_{3}(\mathrm{a})$; $\mathrm{NaCl}+\mathrm{FeCl}_{3}+\mathrm{DCE}$ (b) and $\mathrm{NaCl}+\mathrm{FeCl}_{3}+\mathrm{DCE}$ (c) 


\subsection{The Mechanism of Ethylene Direct Chlorination}

In contrast to the mechanism of reaction (1) described by Lebedev et al. [12], we suppose that at the second stage the $\mathrm{FeCl}_{3}$ catalytic complex transforms into a catalytic complex with $\mathrm{NaCl}$ of donor-acceptor type $\mathrm{Na}\left(\mathrm{FeCl}_{4}\right)$ (reactions 2-3), which reacts with ethylene according to reaction (4). The regeneration of the catalyst and promoter takes place according to reaction (5) [13].

Moreover, we believe that in a medium of liquid dichloroethane the process proceeds by another mechanism, involving a dispersed and partially dissolved catalyst and promoter $\left(\mathrm{FeCl}_{3}, \mathrm{NaCl}\right)$, as well as chlorine and ethylene. The rate of the reactions in ionic form between the catalyst promoter and the reagents is higher than that during the interaction of individual gaseous reagents with each other, and the reaction mechanism involves possible formation of transition complexes of ferrates and dissolved ethylene (reactions (4) and (5)), similar to the mechanism of ethylene oxidation chlorination proposed by us [6].

In addition, along with the ionic reaction mechanism under adverse conditions, namely at high temperatures $(\geq 373 \mathrm{~K})$ and reduced concentrations of catalyst and promoter, a free radical process of ethylene substituted chlorination to 1,1,2-trichloroethane (TCE) may occur [14].

$$
\begin{gathered}
\mathrm{FeCl}_{3}+\mathrm{Cl} \rightarrow \mathrm{FeCl}_{4}^{-} \\
\mathrm{FeCl}_{4}^{-}+\mathrm{NaCl} \rightarrow \mathrm{Na}\left(\mathrm{FeCl}_{4}\right)+\mathrm{Cl}^{-} \\
\mathrm{Na}\left(\mathrm{FeCl}_{4}\right)+4 \mathrm{C}_{2} \mathrm{H}_{4} \rightarrow \mathrm{Na}\left[\mathrm{Fe}\left(\mathrm{C}_{2} \mathrm{H}_{4} \mathrm{Cl}\right)_{4}\right] \\
\mathrm{Na}\left[\mathrm{Fe}\left(\mathrm{C}_{2} \mathrm{H}_{4} \mathrm{Cl}\right)_{4}\right]+4 \mathrm{Cl}_{2} \rightarrow \mathrm{Na}\left[\mathrm{FeCl}_{4}\right]+ \\
+4 \mathrm{C}_{2} \mathrm{H}_{4} \mathrm{Cl}_{2} \\
\mathrm{CH}_{2}=\mathrm{CH}_{2}+2 \mathrm{Cl}^{\bullet} \rightarrow \mathrm{ClCH}_{2}-\mathrm{CH}_{2}{ }^{-}+\mathrm{Cl}^{\bullet} \rightarrow \\
\rightarrow \mathrm{ClCH}_{2}-\mathrm{CH}_{2} \mathrm{Cl}^{*} \\
\mathrm{ClCH}_{2}-\mathrm{CH}_{2} \mathrm{Cl}^{*}+\mathrm{Cl}_{2} \rightarrow \\
\rightarrow \mathrm{ClCH}_{2}-\mathrm{CHCl}_{2}+\mathrm{Cl}^{\bullet}+\mathrm{H}^{*} \\
\mathrm{H}^{*}+\mathrm{Cl}^{*} \rightarrow \mathrm{HCl}^{-} \\
\mathrm{C}_{2} \mathrm{H}_{4} \mathrm{Cl}_{2}+\mathrm{Cl}_{2} \rightarrow \mathrm{C}_{2} \mathrm{H}_{4} \mathrm{Cl}_{3}+\mathrm{HCl}
\end{gathered}
$$

According to the literature data, a radical mechanism of substituted chlorination of already formed DCE to TCE (reactions (6)-(9)) is also possible [15]. In both cases the formation of hydrogen chloride takes place, which worsens the conditions of obtaining DCE via an ionic mechanism. Hydrogen chloride $(\mathrm{HCl})$ contaminates the reaction medium and leads to the equipment corrosion [16]. Apart from that, with excess of chlorine and ferrum(III) chloride a hydrogen substitution in DCE may occur with the formation of TCE and tetrachloroethane, which we previosly identified in DCE and described as chlorination by-products [17].

\subsection{Effect of Sodium Chloride Dispersion}

To study the mechanism and determine the possible influence of the quality and dispersion of the catalyst and promoter in the reaction of liquid-phase direct chlorination of ethylene, we studied [6] the industrial stage of ethylene direct chlorination. Statistics were collected regarding real concentrations of sodium chloride and ferrum(III) chloride in DCE. Chromatographic determination of the DCE purity and the amount of trace impurities in DCE were performed. As can be seen from the data presented in [20], with a gradual decrease in the concentration of catalyst and promoter to the optimal ratio of 1500:50, the DCE purity increases from 99.13 to $99.88 \%$. The concentration of unreacted ethylene and vinyl chloride in impurities decreases almost twice - to $0.01-0.1 \%$. At the same time, the concentration of carbon tetrachloride, chloroform and other impurities formed as by-products of ethylene direct catalytic chlorination is significantly reduced.

The effect of the particle size of the catalyst and promoter [18], their surface and distribution efficiency in DCE is a known fact. Therefore, we investigated the solubility of sodium chloride depending on the degree of grinding of crystalline $\mathrm{NaCl}$ particles in a laboratory ball mill. After grinding, the sodium chloride powder was unloaded from the mill and separated by scattering on sieve with the sizes of 45,65 and $120 \mu \mathrm{m}$. Then the selected fractions of the sieving were dissolved under standard conditions in dichloroethane under heating and stirring. The results obtained are given in [20]. The next step was to change the dissolution temperature of sodium chloride in the range of $323-351 \mathrm{~K}$ and to determine the change in the concentration of dissolved sodium chloride in 1,2-dichloroethane, the results of which are also presented in [20].

The solubility is also affected by the mixing intensity of the components [19]. Therefore, we additionally studied the effect of the stirring intensity on the solubility of DCE components at heating. The data are presented in Fig. 5.

The results of mutual influence of sodium chloride and ferrum(III) chloride on dissolution in DCE under standard conditions $(N=300 \mathrm{rpm}, T=351 \mathrm{~K}$, particle size is $63 \mu \mathrm{m}$ and dissolution time is $1 \mathrm{~h}$ ) are also presented in Fig. 5.

The studies of the $\mathrm{NaCl}$ solubility in DCE depending on the temperature showed that with the increase in temperature from 293 to $323 \mathrm{~K}$ and $351 \mathrm{~K}$, the solubility of $\mathrm{NaCl}$ increased from 2.9 to $30.6 \mathrm{ppm}$ and reached a maximum value of $36.6-37.0 \mathrm{ppm}$ at $351 \mathrm{~K}$. To obtain more reliable data, we studied the efficiency of $\mathrm{NaCl}$ dissolution from the stirring intensity of crystalline $\mathrm{NaCl}$ 
in DCE. For this purpose the dissolution without and with stirring $(I=100-300 \mathrm{rpm})$ were compared.

The increase in stirring intensity increases the efficiency of $\mathrm{NaCl}$ and $\mathrm{FeCl}_{3}$ joint dissolution, thus achieving the optimal ratio of catalyst and promoter (Figs. 5 and 6).

Additionally, we investigated the dependence of the promoter solubility on its particle size; the results are presented in Fig. 5. The decrease in the crystals size from 120 to $40 \mu \mathrm{m}$ increases $\mathrm{NaCl}$ concentration in DCE from 10 to $35 \mathrm{ppm}$. This indicates that $\mathrm{NaCl}$ solubility in $\mathrm{DCE}$

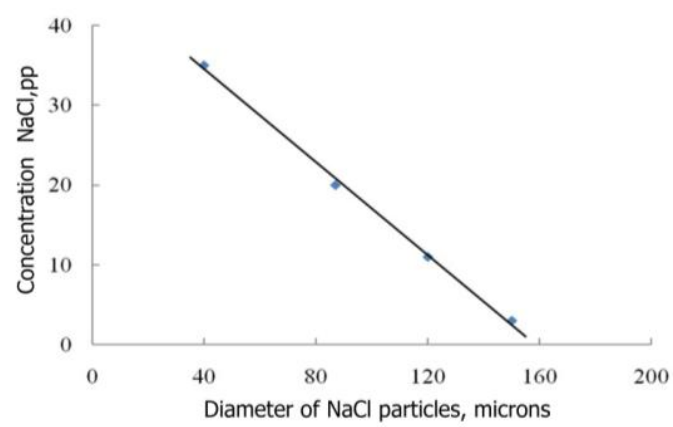

a)

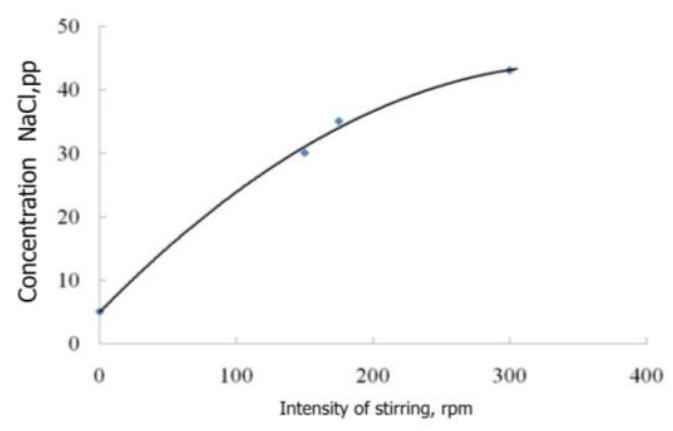

c) depends on the particle size and the diffusion factors at dissolution.

As can be seen from Fig. 5b, the solubility of sodium chloride in DCE increases by 4 times with the increase in temperature from 293 to $351 \mathrm{~K}$. This confirms our assumption that the mechanism of $\mathrm{NaCl}$ dissolution in DCE has a complex physico-chemical character. This assumption is also confirmed by the dependence of $\mathrm{NaCl}$ concentration in DCE on the stirring intensity during catalyst dissolution (Fig. 5c). With increasing stirring intensity the amount of dissolved (dispersed) $\mathrm{NaCl}$ in DCE increases by more than 4 times.

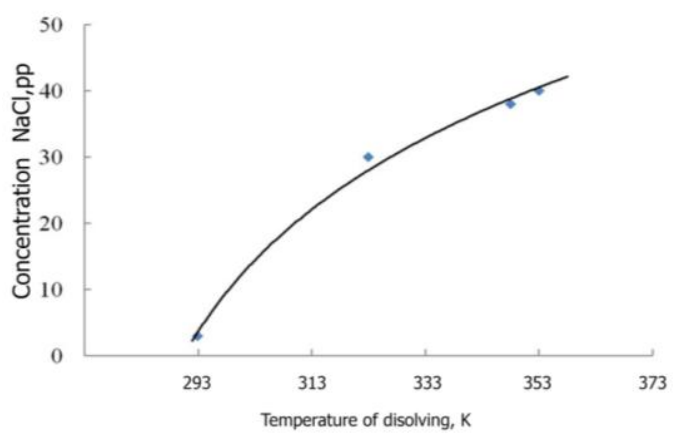

b)

Fig. 5. $\mathrm{NaCl}$ concentration $v$. $\mathrm{NaCl}$ particles diameter (a), temperature (b) and stirring intensity (c) for the catalyst promoter of ethylene direct chlorination. $T=351 \mathrm{~K}$ for (a) and (c)

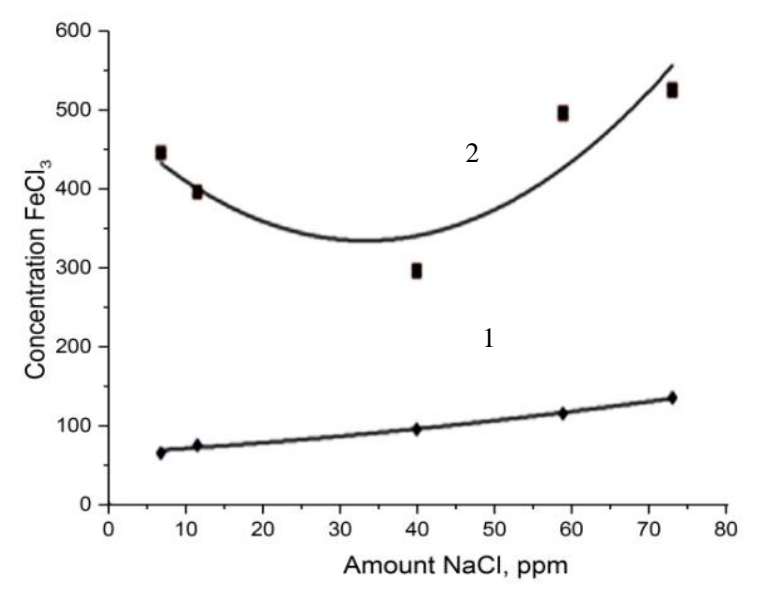

Fig. 6. $\mathrm{FeCl}_{3}$ concentration vs. amount of $\mathrm{NaCl}$ taken for dissolution in DCE at $351 \mathrm{~K}$ at different stirring time: $1 \mathrm{~h}$ (1) and $2 \mathrm{~h}$ (2) 
Fig. 6. represents the mutual influence of the $\mathrm{FeCl}_{3}$ catalyst and the $\mathrm{NaCl}$ promoter in DCE. At the stirring time of $1 \mathrm{~h}$, the concentration of dissolved $\mathrm{FeCl}_{3}$ increases slightly from 50 to $100 \mathrm{ppm}$ with increasing $\mathrm{NaCl}$ concentration (Fig. 6, curve 1). This indicates that under these conditions a complex between $\mathrm{NaCl}$ and $\mathrm{FeCl}_{3}\left(\mathrm{NaFelCl}_{4}\right)$ is not formed. The increase in intensity and stirring time to $2 \mathrm{~h}$ (Fig. 6, curve 2), a chemical interaction of $\mathrm{FeCl}_{3}$ with $\mathrm{NaCl}$ occurs, and the concentration of $\mathrm{FeCl}_{3}$ decreases from 450 to $350 \mathrm{ppm}$. However, further increase in $\mathrm{NaCl}$ concentration to $80 \mathrm{ppm}$ leads to slight increase in $\mathrm{FeCl}_{3}$ catalyst concentration to $500 \mathrm{ppm}$. Obviously, in the first case the $\mathrm{NaFeCl}_{4}$ catalytic complex is formed according to the reactions (3) and (4) and the concentration of pure $\mathrm{FeCl}_{3}$ decreases. The mechanism of direct chlorination with the participation of the catalyst and promoter can proceed according to the reactions (2) and (3). When the promoter concentration is higher than the equimolar one of 40-50 ppm, it no longer interacts with $\mathrm{FeCl}_{3}$ and the concentration of pure $\mathrm{FeCl}_{3}$ in DCE increases, which is observed in the plots (Fig. 6). This leads to a significant increase in the $\mathrm{FeCl}_{3}$ concentration, decrease in the yield of the main product and increase in the number of byproducts of trichloroethane and tri- and tetrachlorethylene formed according to the substitution reactions (8) and (9). The same situation is observed for the excess content of $\mathrm{NaCl}$. The weight ratio of $\mathrm{NaCl}$ to the catalytic complex with $\mathrm{FeCl}_{3}$ is $1: 10$. Obviously, the same concentration ratio can be achieved during dissolution in DCE, which is confirmed by obtained dependences (Figs. 5 and 6). So, the concentration ratio of $\mathrm{NaCl}: \mathrm{FeCl}_{3}$ in DCE is reached as 50:(500-1000) ppm, i.e. 1:(10-20).

The analysis of the statistics showed that the increase in $\mathrm{FeCl}_{3}$ concentrations above $800 \mathrm{ppm}$ and $\mathrm{NaCl}$ concentration above $50 \mathrm{ppm}$ impairs the DCE purity and increases the amount of trichloroethane, trichlorethylene and tetrachlorethylene [6]. Increasing the temperature to $373 \mathrm{~K}$, time, stirring intensity and reducing the particle size of crystalline $\mathrm{NaCl}$ to $63 \mu \mathrm{m}$ or less increases the final concentration of $\mathrm{NaCl}$ and $\mathrm{FeCl}_{3}$ in $\mathrm{DCE}$ by several times (Fig. 5).

Thus, the excess amount of $\mathrm{NaCl}$ above $400 \mathrm{ppm}$ negatively affects the final concentration of $\mathrm{FeCl}_{3}$ in DCE and decreases it to a certain extent, but later this effect is counterbalanced by increasing time and dissolution intensity. However, the excess of undissolved $\mathrm{NaCl}$ (appro-ximately
$400-50=350 \mathrm{ppm}$ ) adversely affects the process and equipment, resulting in the equipment corrosion and reduction of DCE purity [20].

\subsection{Stabilization of the Catalytic Complex}

Despite numerous experiments on studying the effect of sodium chloride dispersion, its solubility in DCE is low. In addition, catalytic complex $\mathrm{Na}\left[\mathrm{Fe}\left(\mathrm{C}_{2} \mathrm{H}_{4} \mathrm{Cl}\right)_{4}\right]$ is unstable and decomposes or precipitates at low temperatures. Considering the experience of other researchers who used as a stabilizer of the catalytic complex the compounds with nitrogen-containing donors such as hexamethylphosphorriamide or pyridine and radical reaction inhibitors such as 2,6-di-tert-butyl-4-methylphenol, $p$-nitrophenol, 2,2-di( $p$-oxyphenyl) propane $[9,10]$ in the chlorination reactions, as well as in oxidation reactions of organic compounds [21], we investigated the effect of ammonium chloride and the sodium salt of perforated sulfonic acid in the amount of $10 \mathrm{wt} \%$ relative to the sodium chloride amount. We used sodium chloride and ammonium chloride of the following fractional composition (Table). The content of iron and sodium ions in an industrial ethylene chloride reactor was monitored.

The introduction of donor compounds (ammonium chloride) into the catalyst did not lead to a positive result (Fig. 7): the content of iron ions varied from 750 to $150 \mathrm{ppm}$ due to different time of sampling and dosing of the catalyst, and the sodium ion content was in the range of $2-6 \mathrm{ppm}$, that is significantly below design values $(50 \mathrm{ppm})$. However, these industrial test data confirm our previous laboratory studies (Fig. 6) on the changes in the $\mathrm{FeCl}_{3}$ concentration [20].

Unlike ammonium chloride, the introduction of the sodium salt of perfluorosulfonic acid (acceptor ligand) into the catalytic system leads to a gradual increase in the content of sodium ions (Fig. 8) during all process, reaches the required values $(50 \mathrm{ppm})$ on the seventh day of industrial testing on LLC "Karpatnaftokhim" and remains unchanged.

Regarding the DCE purity, it increases from 97 to $99.5 \%$ and the trichlorethane (by-product) content decreases from 0.58 to $0.25 \%$ (Fig. 9).

Thus, the main factor contributing to the dissolution of sodium chloride in DCE is not only its dispersion, but also the presence of a catalyst complex stabilizer.

Fractional composition of sodium chloride and ammonium

\begin{tabular}{|c|c|c|c|c|c|}
\hline \multirow{2}{*}{$\begin{array}{c}\text { Mixture of chlorides } \\
\text { Date }\end{array}$} & \multirow{2}{*}{$\begin{array}{c}\text { Moister } \\
\text { content, \% }\end{array}$} & $0.2 \mathrm{~mm}$ & $0.09 \mathrm{~mm}$ & $0.045 \mathrm{~mm}$ & $<0.045 \mathrm{~mm}$ \\
\cline { 3 - 6 } & 0.15 & 46.1 & 46.9 & 6.5 & 0.3 \\
\hline 27.07 .2018 & 0.16 & 59.3 & 24.5 & 14.9 & 0.4 \\
\hline 25.10 .2018 & & &
\end{tabular}




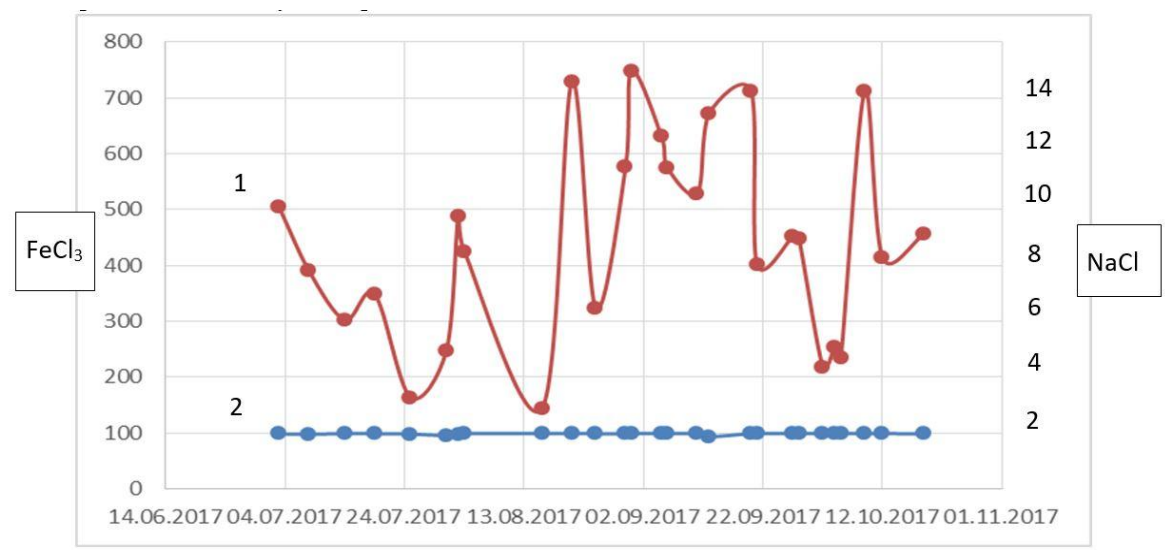

Fig. 7. Dependence of ferrum (1) and sodium (2) ions content on the time during the ethylene direct chlorination in the presence of ammonium chloride

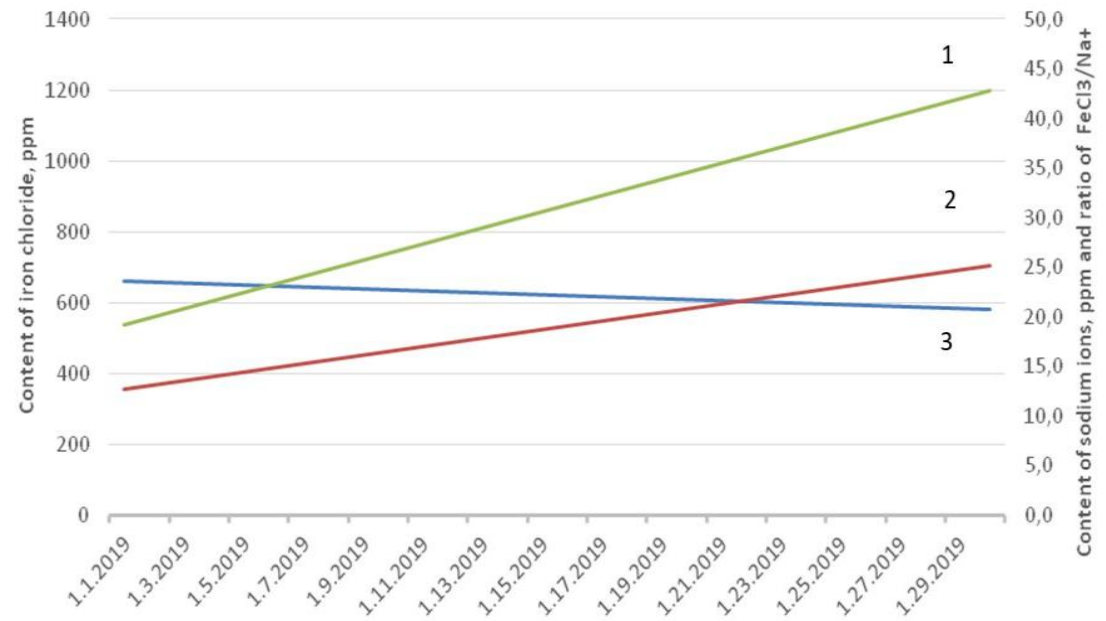

Fig. 8. Dependence of ferrum (3), sodium (2) ions content and their ratio (1) on the time during the ethylene direct chlorination in the presence of perfluorosulfonic acid sodium salt

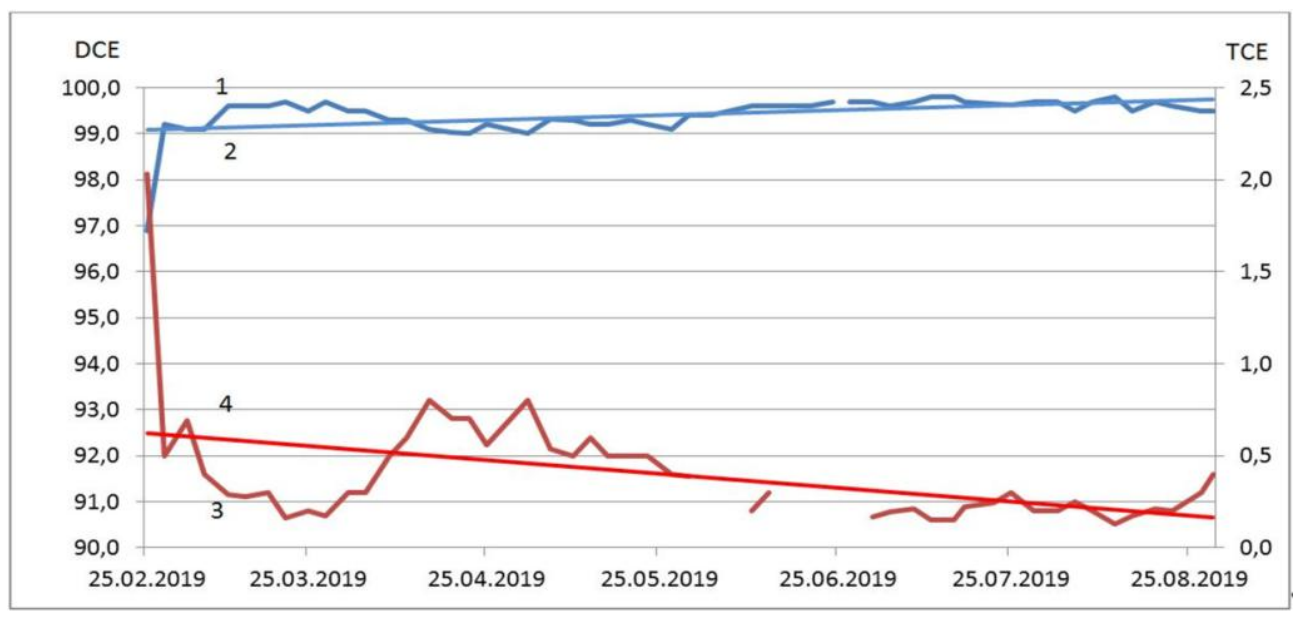

Fig. 9. The dependence of the DCE purity $(1,2)$ and the trichloroethane content $(3,4)$ on the time during the ethylene direct chlorination in the presence of perfluorosulfonic acid sodium salt:

1,3 - running values; 2,4 - averaged values 


\section{Conclusions}

The dependence of solubility of sodium chloride and ferrum(III) chloride as the catalyst and promoter of ethylene direct chlorination in DCE on the grinding degree of crystalline sodium chloride, the dissolution temperature, the stirring intensity, and the mutual influence of the catalyst components has been studied. The positive effect of all investigated process parameters on the increase of sodium chloride and ferrum(III) chloride concentration in DCE was shown.

The mechanism of ethylene direct chlorination was found to be dependent on the concentration of catalyst and promoter and their complex compound $\left(\mathrm{NaFeCl}_{4}\right)$, as well as their transition complex with ethylene $\left(\mathrm{Na}\left[\mathrm{Fe}\left(\mathrm{C}_{2} \mathrm{H}_{4} \mathrm{Cl}\right)_{4}\right]\right)$. In our opinion the process takes place in the diffusion zone, which provides the possibility of forming complex compounds between catalyst, promoter and ethylene via the novel reaction mechanism proposed in this work.

Using DTA, X-ray diffraction and mass spectrometry the metal-complex mechanism of the ethylene direct chlorination reaction described by reactions (2)-(5) was specified.

The introduction of a stabilizer (perfluorosulfonic acid sodium salt) into the catalytic complex results not only in the increase of sodium ions content in it till its design value, but also in the increase of DCE purity and the decrease of by-products content. In this case, the dispersion of the catalytic system is also important, which confirms the cyclicality of the catalytic complex formation on an industrial scale.

\section{References}

[1] Postiyny Technolohichny Reglament Tschu Vyrobnytstva Chlorystoho Vinilu: "Fridrich Ude" and JSC "CHimengemeering" V-35/95, Kalush 1991-1995.

[2] Flid M., Treger Yu.: Vinilkhlorid. Khimiya i Tekhnologiya. Kalvis, Moskva 2008.

[3] Treger Y., Gudzhanovskaya T.: Intensifikatsia

Chlororganicheskich Produktov. Vusokoefektivnue Kataliticheskie Sistemy. Khimiya, Moskva 1989. P.79.

[4] Furman A.: Neorganicheskie Chloridy (Khimia i Technologia). Khimia, Moskva 1980.

[5] Kurta S.: Khimia i Technologia Chloorhanichnych Spoluk. Plai, Ivano-Frankivsk 2009.

[6] Kurta S., Haber M., Mykytyn I.: Khim. Prom. Ukrainy, 2003, 6, 33.

[7] Balchugov V. et al.: Pat. RU 2159759 C2, Publ. Nov. 27, 2000.

[8] Avetjan M., Sonin E., Zaidman O.:Khim. Prom., 1991, 12, 710.
[9] Bodrikov I., Bolshakova L., Groshev G.: Pat. RU 2071461, Publ. Jul. 13, 1993

[10] Kurta S., Mykytyn I., Tatarchuk T.: Nanoscale Res. Lett., 2014, 9, 357.

[11] Meibner R., Hesse M., Walsdorff C.: Pat. Germany

US2001011149, Publ. Aug. 02, 2001.

[12] Lebedev N.: Khimia i Technologia Osnovnoho

Organicheskoho i Neftechimicheskoho

Synteza. Khimia, Moskva 1975.

[13] Oshin L., Treger Yu., Motsarev

G.: Promyshlennye Chloorganicheskie Producty

(Spravochnik). Khimia, Moskva 1978.

[14] Dmitriev Yu., Kats M., Gorin V.: Pat. RU 2159759

C2, Publ. Nov. 27, 2000.

[15] Werk G., Grumann H., Stoger M.: Pat. Germany

10059229, Publ. Jun. 13, 2002.

[16] Halonen J., Tarhanen J.,

Ruokojarvi P. et al.: Chemosphere, 1995, 30, 1261. https://doi.org/10. 1016/0045-6535(95)00022-Z

[17] Kurta S.: Chem. Chem. Technol., 2012, 6,

1. https://doi.org/10.23939/chcht06.01.001

[18] Krentsel B.: Chlorirovanye Parafinovykh Uglevodorodov. Nauka , Moskva 1964

[19] Alimov V., Duriahina Z.: Korozia ta Zachyst Metaliv vid Korozii. "Shidny vudavnychyi dim", Donetsk-Lviv 2012.

[20] Kurta S., Mikitin I., Khatsevich O., Ribun V.: Teor. i Exp. Khim., 2018, 34, 258.

[21] Mokry E., Ludyn A., Reutskiy V.: Dopov. Acad. Nauk Ukrainy, 1993, 7, 99

Received: October 02, 2019/ October 18, 2019 / Accepted: November 15, 2019

\section{МОДИФІКАЦІЯ КАТАЛІТИЧНОЇ СИСТЕМИ ПРОМИСЛОВОГО ПРОЩЕСУ ПРЯМОГО ХЛОРУВАННЯ ЕТИЛЕНУ В 1,2-ДИХЛОРЕТАН}

Анотація. Запропоновано новий механізм реакиіі прямого (адитивного) хлорування етилену з утворенням 1,2дихлоретану в присутності каталізатора $\mathrm{FeCl}_{3}$, промотованого $\mathrm{NaCl}$. Встановлено, шо швидкість залежить від концентрачії активної фази каталізатора і промотора, а також утворення комплексу $\mathrm{Na}\left[\mathrm{Fe}\left(\mathrm{C}_{2} \mathrm{H}_{4} \mathrm{Cl}\right)_{4}\right]$, який $\epsilon$ поверхневим інтермедіантом реакиії. Обгрунтовано гетерогенно-гомогенний механізм процесу, згідно якого реакиія починається на поверхні каталітичного комплексу $i$ триває в розчині дихлоретану. Запропоновано стабілізатор каталізаторного комплексу - натрієву сіль перфорованої сульфокислоти, яка дозволяє прискорити прочес розчинення хлориду натрію, підвищити селективність утворення 1,2-дихлоретану та зменшити кількість побічних продуктів - трихлоретану та інших хлорпохідних.

Ключові слова: етилен, хлор, дихлоретан, адитивне хлорування, каталізатор, промотор, конверсія, , стабілізатор, хлорид амонію, натрієва соль перфорованої сульфокислоти. 